\title{
The Relation Between The Pre-service Elementary Teachers' Levels of Relating Science Knowledge to Daily Life and Their Attitude and Scientific Literacy*
}

\author{
Mustafa ÜREY ${ }^{* *}$
}

\author{
Lale CERRAH ÖZSEVGEÇ ${ }^{* * *}$
}

Received: 22 May 2014

\begin{abstract}
The aim of this study is to determine the preservice elementary teachers' levels of relating the science knowledge to their daily life and to examine the relation between preservice teachers' levels of connecting science knowledge that they acquire in science course with their attitudes and scientific literacy. The case study method was employed in the study. The sample of the study comprised 200 second year preservice elementary teachers in KTU Fatih Faculty of education. The data were collected with scientific literacy test, daily life relating test and attitude questionnaire during the Science and Laboratory Application II Lesson. The problem situations were created for boiling, melting, freezing, expansion, excretion, digestion, heat and temperature concepts. The results of the study indicated that the preservice teachers' levels of relating science knowledge to daily life situations were very low.
\end{abstract}

Keywords: Preservice elementary teachers, science knowledge, daily life, scientific knowledge, attitude

\section{Extended Abstract}

Purpose and Significance: The aim of this study is to determine the preservice elementary teachers' levels of relating their science knowledge to their daily life and to examine the relation among the preservice teachers' levels of connecting science knowledge that they acquire in science course and their attitudes and scientific literacy. In line with this purpose, this study sought to explore the following research questions:

1. What is the relation among the preservice elementary teachers' levels of relating their science knowledge to their life and their attitudes and scientific literacy?

2. What are the misconceptions of the preservice elementary teachers about science knowledge related with boiling, melting, freezing, expansion, excretion, digestion, heat and temperature?

Methods: The case study method was employed in the study The sample of the study comprised 200 second year preservice elementary teachers in KTU Fatih Faculty of education. The data were collected with scientific literacy test, daily life relating test and attitude questionnaire during the Science and Laboratory Application II Lesson.

\footnotetext{
* This paper is an extended version of the oral presentation of 9th National Science and Mathematics Education Congress (23rd-25th September, 2010) held in İzmir at Dokuz Eylül University.

** Corresponding Author:Assoc. Prof. Dr., Karadeniz Technical University, Trabzon, Turkey, murey01@gmail.com

*** Assoc. Prof. Dr., Karadeniz Technical University, Trabzon, Turkey, lalecerrah@yahoo.com
} 
Results: The statical analysis showed that there is a significant relation between the preservice elementary teachers' scientific literacy and their attitudes to science $(r=0.58$; $\mathrm{p}=0.000, \mathrm{p}<0.01$ ). On the other hand, it was determined that there is a weak but positive relation between the preservice elementary teachers' scientific literacy and applying the science knowledge to the situations encountered in their lives $(r=0.32 ; p=0.001$, $\mathrm{p}<0.01$ ). As the relation values are examined, it is seen that the positive attitude to the science is more effective than the scientific literacy level to transfer the scientific knowledge to the situations in daily life. The findings of the Daily Life Relating Test indicated that the preservice elementary teachers had misconceptions about the freezing, boiling, digestion, excretion, heat and light. Their scientific explanation ratios are very low. They believe that the kidneys and lungs are the organs of the digestive system. They have conceptual conflict between the excretion and elimination and also heat and the temperature. They have little knowledge about what increases or decreases the boiling point of a liquid. The preservice elementary teachers' graphical presentations were also problematic. Most of them drew the graphic of phase changing of water incorrectly. The preservice elementary teachers' interview data showed that the courses related with the science in the university were also inadequate at this point. Lectures are not presenting the relation among the science subject and its daily practices adequately and the examples in the lives. The preservice elementary teachers are mostly memorizing what they were taught. Science and Laboratory Application Course is also inadequate to support preservice elementary teachers daily life knowledge.

Discussion and Conclusions: As other studies are revealed, this study also showed that the students are memorizing the knowledge without internalizing or understanding it. They believe that the subject they are taught is not necessary for them and they will not use this knowledge in their lives. Teachers mostly use didactive methods to teach the subject and don't give adequate examples from daily life practices. This kind of teaching may be resulted with misconceptions and weak understanding. The findings of the Daily Life Relating Test support this point of view. Preservice elementary teachers had weak understanding about freezing, boiling, heat, digestion and excretion concepts. Because of their limited knowledge, they could not apply their science knowledge to the daily life experiences and they could not explain the reason of the given problem statements scientifically. The answers of the preservice elementary teachers showed that they answered the questions based on their daily experiences not scientific knowledge. Other reason of this learning problem may be the content of the science courses. The preservice elementary teachers believe that their science courses contents' don't overlap with the science curriculum of the primary school. They are learning many things but they will not teach them to their students. This kind of view decreases their motivation to learning science. Preservice elementary teachers are learning the theory of the science without connecting it with daily life experiences. As a result of this, they generally have weak understanding and many misconceptions. This situation decreases their achievement, attitudes and their level of relating science knowledge to everyday life 
problems. Based on the findings it can be said that there is a significant relation among the students' knowledge, attitudes and application of scientific knowledge to the real problems in the life. Teachers pay attention to use different teaching methods and to give more examples from the student's daily life. It should the emphasized that the science is a part of our life. The other important point that the studies showed that the teachers and the students had similar misconceptions. This may be interpreted that the teachers may transfer their misconceptions to their students. It is suggested that the preservice teachers' science knowledge should be examined and treated before they become a teacher. They should be informed about the real life applications of the given subject. When they become a teacher they can be also motivate their own students about the importance of science in our life practices. 


\title{
Sınıf Öğretmen Adaylarının Fen Bilgilerini Günlük Yaşamla İlişkilendirebilme Düzeyleri ile Fen Tutum ve Okuryazarlıkları Arasındaki İlişki*
}

\author{
Mustafa ÜREY ${ }^{* *}$
}

\author{
Lale CERRAH ÖZSEVGEÇ ${ }^{* * *}$
}

Makale Kabul Tarihi: 29 Nisan 2015

\begin{abstract}
ÖZET: Bu çalışmanın amacı, sınıf öğretmen adaylarının fen bilgilerini günlük yaşamla ilişkilendirebilme düzeylerini tespit ederek, adayların fenne karşı tutumları ve fen okuryazarlıkları ile günlük yaşam ilişkilendirmeleri arasındaki ilişkiyi araştırmaktır. Çalışmanın örneklemini, KTÜ Fatih Eğitim Fakültesi Sınıf Öğretmenliği Bölümü 2.sınıfta öğrenim gören 200 öğretmen adayı oluşturmaktadır. Araştırma verileri, fen okuryazarlık (FOYT) ve günlük yaşam ilişkilendirme testi (GYİT) ile fen tutum ölçeği (FTÖ) kullanılarak toplanmıştır. Fen ve Teknoloji Laboratuar Uygulamaları (FTLU)-II dersi kapsamında yürütülen araştırmada, günlük yaşantımızda sıkça karşılaştığımız kaynama, erime, donma, genleşme, boşaltım, sindirim, 1sı ve sıcaklık kavramlarına yönelik problem durumları oluşturulmuştur. Elde edilen bulgular, öğretmen adaylarının öğrendikleri bilgileri günlük yaşamda karşılaştıkları durumlara uygulayabilme düzeylerinin oldukça düşük olduğunu ortaya koymuştur.
\end{abstract}

Anahtar sözcükler: Öğretmen adayları, fen bilgisi, günlük yaşamla ilişkilendirme, sınıf öğretmenliği, tutum

\section{Giriş}

Son yıllarda yapılan çalışmalar incelendiğinde, öğrenme ve günlük yaşamla ilişkilendirme kavramlarının birlikte kullanıldığ araştırmalarda artış olduğu görülmektedir. Bu iki kavramın tanımları incelendiğinde aralarında sıkı bir ilişki olduğu görülebilmektedir. Günlük yaşam kavramı, toplum içinde yaşamını sürdüren bir bireyin çevresinde meydana gelen ve rutin bir şekilde devam eden olaylar ve hareketler dizisi şeklinde açıklanmaktadır (McCann, 2001). Öğrenme, bireyin olgunlaşma düzeyine göre yaşantıları aracılı̆̆ıla ya da çevresiyle etkileşimi sonucunda yeni davranışlar kazanması ya da eski davranışlarını değiştirmesi sürecidir (Senemoğlu, 2009). Bu tanımlamalar öğrenmenin gerçekleşmesinde, günlük yaşamın etkili olduğu sonucunu da açıkça ortaya koymaktadır.

Fen eğitiminin temel hedeflerinden biri, öğrencilerin öğrenimleri sırasında edindikleri bilgileri günlük yaşantılarında kullanabilmelerini sağlayabilmektir. Öğrencilerin Fen ve Teknoloji dersinde öğrendikleri bilgileri günlük yaşamlarında karşılaştıkları olaylara yansıtabilmeleri ve problemlerin çözümünde kullanabilmeleri hem verilen öğretimin başarısının hem de bilgilerin kalıcıllğının sağlanmasının göstergesi olarak kabul edilebilir (Ayas, Coştu ve Ünal, 2007; Anagün, Ağır ve Kaynaş, 2010). Fen ve teknoloji programının temelini oluşturan, yapılandırmacılık fikrinin ortaya çıkmasında etkili olan Piaget, Dewey, Vygotsky ve Bruner gibi kuramcılar da bilgilerin günlük yaşamla ilişkilendirilmesi ve hatta yaşamın bir parçası olması durumunda birey tarafından rahatlıkla içselleştirilebileceği görüşünde birleşmektedirler (Aydın, 2000; Özden, 2003). Bireyler, sorunlarını çözmek ve yaşamlarını kendi

\footnotetext{
* Bu çalışma, İzmir 9 Eylül Üniversitesi Buca Eğitim Fakültesi’nde düzenlenen IX. Ulusal Fen Bilimleri ve Matematik Eğitimi Kongresi (23-25 Eylül 2010)' nde sunulmuş sözlü bildirinin genişletilmiş halidir.

${ }^{* *}$ Sorumlu Yazar: Yrd. Doç. Dr., Karadeniz Teknik Üniversitesi, Trabzon, murey01@gmail.com

**** Doç. Dr., Karadeniz Teknik Üniversitesi, lalecerrah@yahoo.com
} 
açılarından kolaylaştırabilmek için belleklerine kaydetmiş oldukları bilgileri bir şekilde kullanmak zorunda kalmaktadırlar (Göçmençelebi ve Özkan, 2009). Başka bir deyişle, bireyin herhangi bir kavramı ya da düşünceyi öğrenebilmesi için o kavramı ya da düşünceyi günlük yaşamında kullanması ve gerekli durumlara uygulayabilmesi gerekmektedir (Kıyıc1-Balkan, 2008; Smith ve Siegel, 2004; Wagner, 2007).

Fen öğreniminde asıl olan, fenne ait kavramların tanımını bilmekten ziyade, öğretilen kavramları gerekli olduğunda bellekten geri çağırmak ve kullanabilmektir. Bu durum, ilgili fen kavramının güncel yaşamda kullanımı ile mümkün olabilmektedir. Bu nedenle özellikle güncel yaşam deneyimine sunulamayan fen kavramlarında kavram yanılgılarına rastlanmaktadır (Baybee, 1998). Çünkü öğrenciler günlük yaşam deneyimi kuramadığı fen kavramları konusunda öğretmenlerinin aktardığı ya da ders kitaplarında yazan ve kendilerine yaramayacağını düşündükleri bilgileri ezberleme yoluna gitmektedirler. Kavramsal anlamaya yönelik literatür incelendiğinde de kavram yanılgılarının nedenlerinden birinin de ilgili kavramın güncel yaşam deneyimine maruz kalmadan öğrencinin zihninde yanlış şekillenmesi olarak ifade edilmektedir (Chi, 2005; Akt. Cobern, Gibson ve Underwood, 1995). Fen kavramlarına yönelik öğrencilerin güncel yaşam deneyimlerine maruz kalmaları ilgili kavramların somutlaştırılmasına katk1 sağladığ1 gibi öğrencilerin fen okuryazarlık düzeylerinin gelişimine (Andree, 2003; Baumert, Bos ve Lehman, 2000; Harlen, 2002; Özmen, 2003) ve öğrencilerin motivasyonunu arttırarak derse yönelik ilgi ve tutumu olumlu yönde değiştirebilmelerine (Black ve Atkin, 1996; OECD, 2003) olanak sağlamaktadır.

Fen okuryazarlığı, başta Amerika Birleşik Devletleri olmak üzere pek çok Avrupa Birliği ülkesinde çağdaş fen müfredatlarının ortak vizyonu olarak kabul edilmekte ve bu kapsamda reformlar gerçekleştirilmektedir (Liu, 2009). Ülkemizde de Fen Bilimleri dersi öğretim programının vizyonu "tüm öğrencileri fen okuryazarı bireyler olarak yetiştirmek" (MEB, 2013) olarak belirlenmiş ve bu kapsamda reformlar gerçekleştirilmiştir. Fen okuryazarlığ1, "bireylerin araştırma-sorgulama, eleştirel düşünme, problem çözme ve karar verme becerileri geliştirmeleri, yaşam boyu öğrenen bireyler olmaları, etraflarındaki dünya hakkındaki merak duygularını sürdürmeleri için gerekli olan fenle ilgili beceri, tutum, değer, anlayıs ve bilgilerinin bir birleşimi” olarak tanımlanmaktadır (Kavak, Tufan ve Demirelli, 2006). Bu kapsamda fen okuryazarlığ "Fen Bilimleri ve Teknolojinin Doğası", "Anahtar Fen Kavramları", "Bilimsel Süreç Becerileri”, "Fen-Teknoloji-Toplum-Çevre İlişkileri”, "Bilimsel ve Teknik Psiko-motor Beceriler", "Bilimin Özünü Oluşturan Değerler" ve "Fenne İlişkin Tutum ve Değerler" olmak üzere 7 boyutta ele alınmaktadır (Balım, Sucuoğlu ve Aydın, 2009). Bunlardan belki de en önemlisi ders kitaplarında sıkça karşılaştığımız “Anahtar Fen Kavramları”dır (Balım ve diğerleri, 2009). Öğrencilerin bilimin doğasını anlayabilmesi, fen-teknoloji-toplum-çevre ilişkisini irdeleyebilmesi, fen hakkında düşünerek ve onu yorumlayarak fene ilişkin ilgi ve tutum geliştirebilmesi, kısaca fen okuryazarı olabilmesi için fen kavramlarını biliyor olması gerekir. Bu nedenle fen eğitiminin ilk amacı fen kavramlarının öğretimi olmalı, kavramlar öğretilirken diğer boyutlar verilmeye çalışılmalıdır. Bu boyutlardan da özellikle "Fene İlişkin Tutum ve Değerler" 
boyutu öğrencinin fen kavramlarına olan motivasyonunu sağlayabilmeleri açısından oldukça önemlidir. Fen okuryazarlığının yedi boyutundan biri olan "Fenne İlişkin Tutum ve Değerler" ile öğrencilerin fen bilimlerine yönelik olumlu bilimsel tutumlar geliştirmeleri amaçlanmaktadır. Fen Bilimleri öğretim programında öğrencilerin sadece bilgi, anlayış ve beceri kazanmaları yeterli görülmemektedir. Bununla birlikte, öğrencilere belirli bilimsel tutum ve değerlerin kazandırılması da ön planda tutulmaktadır.

Öğrenciler için birincil bilgi kaynağı öğretmenlerdir. Öğretmenlerin anlaml öğrenmeyi beklenen düzeyde gerçekleştirebilmeleri için öğrettikleri bilgilerin günlük yaşam ilişkilendirmelerini yapabilecek fen okuryazarlığına ve aynı zamanda fenne karşı üst düzey ilgi ve tutuma sahip olmaları gerekmektedir. Alan bilgisi zayıf, fenne karşı olumlu tutuma sahip olmayan öğretmenlerin etkili öğretim yapamadıkları belirtilmektedir (Berg ve Brouwer, 1991; Halim ve Meerah, 2002; Yaman, 2009). Casaj (1999), öğretmenlerin yüksek öğrenimleri sürecinde yeterli eğitime ve deneyime sahip olamadıkları için günlük yaşamla ilişkilendirme konusunda problem yaşadıklarını belirtmektedir. Öğretmenlerin hizmet sürecinde bu tip problemleri yaşamamaları için de hizmet öncesinde gerekli çalışmaların yürütülmesi oldukça büyük önem taşımaktadır. $\mathrm{Bu}$ çalışmanın önemini artıran diğer bir nokta ise ilköğretim öğretmen adaylarının örneklem olarak seçilmesidir. İlköğretim temel bilgilerin verildiği kademedir. Öğrencilerin ilköğretim sürecindeki öğrenme problemlerini sonraki kademelere taşıdığını gösteren pek çok çalışma mevcuttur (Atasoy ve Akdeniz, 2005; Çalık ve Ayas, 2005). Bu bağlamda, ilköğretim birinci kademesinde öğretmenlik yapacak öğretmen adaylarının fen bilgilerini günlük yaşamda kullanabilme düzeylerinin belirlenmesi temel eğitimin kalitesinin artırılması açısından ayrı bir öneme sahiptir. Ayrıca bu çalışmada diğer çalışmalardan farklı olarak, adayların günlük yaşamla ilişkilendirme düzeyleri ile tutumları ve fen okuryazarlıkları arasındaki ilişki de incelenmiştir.

$\mathrm{Bu}$ çalışmanın amacı, sınıf öğretmen adaylarının fen konularına yönelik günlük yaşam ilişkilendirmelerindeki yanılgıları ortaya koyarak, öğretmen adaylarının fen tutum ve okuryazarlıkları ile günlük yaşam ilişkilendirmeleri arasındaki ilişkiyi araştırmaktır.

$\mathrm{Bu}$ amaç doğrultusunda aşağıdaki sorulara cevap aranmıştır:

1. Sınıf öğretmeni adaylarının fen okuryazarlıkları, fenne karşı tutumları ve günlük yaşam ilişkilendirmeleri arasındaki ilişki ne düzeydedir?

2. Sınıf öğretmeni adaylarının günlük yaşam ilişkilendirmelerine yönelik yanılgıları nelerdir? 


\section{Yöntem}

\section{Araştırma Modeli}

Araştırmada Özel Durum Çalışması (Case Study) kullanılmıştır. Özel durum çalışmaları, belirli bir fenomene ait bir örneği (özel durumu) derinlemesine inceleyerek fenomene 1şık tutmayı amaçlayan araştırmalardır. Araştırma sürecinde ortam, birey veya süreçler bütüncül bir yaklaşımla incelenmekte, süreci etkileyen roller ve ilişkiler üzerine odaklanılmaktadır. Ayrıca özel durum çalışmalarının birden fazla veri toplama tekniğinin kullanılmasına olanak sağlaması, zengin ve birbirini destekleyecek veri çeşitliliğine ulaşılmasına katkıda bulunabilmektedir (Çepni, 2010).

\section{Araştırmanın Çalıșma Grubu}

Araştırma, 2009-2010 eğitim-öğretim yılı bahar döneminde KTÜ Fatih Eğitim Fakültesi Sınıf Öğretmenliği Bölümü 2.sınıfta öğrenim gören 200 öğretmen adayı ile gerçekleştirilmiştir. Araştırmaya katılan öğretmen adaylarından 121'i kız, 79'u erkek öğretmen adayından oluşmaktadır. Öğretmen adayları, çalışmanın yapıldığı döneme kadar ki süreçte Genel Fizik, Genel Kimya ve Canlılar Bilimi derslerini almışlardır.

\section{Veri Toplama Araçları}

Araştırmada fen okuryazarlık testi (FOYT), günlük yaşam ilişkilendirme testi (GYIT), fen tutum ölçeği (FTÖ) ve yarı yapılandırılmış mülakat kullanılmıştır. Test soruları hazırlanırken, günlük yaşantımızda sıkça karşılaştığımız konuların ve 5. sınıf düzeyinde ders kitaplarında geçen anahtar kavramların seçimine özen gösterilmiştir. Öğretmen adaylarının sunumlarına ait gözlemler de dikkate alınarak "kaynama, donma, erime, boşaltım, sindirim, genleşme, isı ve sicaklık” konuları araştırma kapsamına alınmıştır.

Fen okuryazarlık testi (FOYT). FOYT (EK-1), fen okuryazarlığ boyutlarından "Anahtar Fen Kavramları" boyutu dikkate alınarak oluşturulmuştur. Bu kapsamda kaynama, erime, donma, genleşme, boşaltım, sindirim, 1sı ve sıcaklık kavramlarına yönelik açık uçlu 7 soru oluşturulmuştur. Soruların oluşturulması esnasında öğretmen adaylarının ilgili kavram hakkındaki bilimsel açıklamaları ve güncel yaşamdan örnekleri alınmaya çalışılmıştır. Böylece öğretmen adayının ilgili kavrama yönelik bilimsel tanımlama yeterlilikleri ve güncel yaşamdaki kullanım alanlarını fark edebilme durumları tespit edilmiştir. Araştırmacılar tarafından oluşturulan test maddeleri alan uzmanı olan üç öğretim üyesi tarafindan incelenirken, alan uzmanlarının görüşleri doğrultusunda her bir kavram için standart soruların oluşturulmasına karar verilmiştir. Böylece, öğretmen adaylarından ilgili kavramları tanımlamaları ve örneklendirmeleri istenen, iç geçerliliğini ve güvenilirliğini güçlendirecek standart sorular (Çepni, 2010) oluşturulmuştur.

FOYT'nin içerik analizinde, öğretmen adaylarının yaptıkları tanımlamalar ve açıklamalar doğrultusunda dört farklı kategori belirlenmiş ve her bir kategori için 
puanlandırma yapılmıştır. FOYT'nin analizi için araştırmacılar tarafindan oluşturulan Rubrik-1 Tablo 1'de sunulmuştur.

Tablo 1

FOYT’nin Analizine Yönelik Rubrik-1

\begin{tabular}{|c|c|c|}
\hline & Kategoriler & Puan \\
\hline Bilimsel & & 3 \\
\hline Kısmen Bilimsel & & 2 \\
\hline Bilimsel Değil & & 1 \\
\hline Boş & & 0 \\
\hline
\end{tabular}

Öğretmen adaylarının her bir soruda yaptıkları bilimsel tanımlar ve açıklamalar için 3, kısmen bilimsel tanımlar ve açıklamalar için 2 ve bilimsel olmayan tanım ve açıklamalar için 1 ve boş bırakılan cevaplar için 0 puan verilmiştir. $\mathrm{Bu}$ durumda adayların FOYT'den alacağı en yüksek puan 21, en düşük puan ise 0'dır.

Günlük yaşam ilişsilendirme testi (GYİT). GYİT, araştırma kapsamındaki kavramların (kaynama, erime, donma, genleşme, boşaltım, sindirim, 1Sı ve sıcaklık) günlük yaşamdaki kullanımlarıyla ilgili durumların yorumlanmasını isteyen 7 açık uçlu sorudan (ilgili kavramlardan 1sı ve sıcaklık kavramları tek bir soru içerisinde verilmiştir) oluşmaktadır. Araştırmacılar tarafından oluşturulan testin ilk halinde sadece soru kökleri yer alırken, uzman incelemesi sonrasında her bir soru için günlük yaşam bağlantısının kurulabileceği senaryoların oluşturulmasına karar verilmiştir. Uzman görüşleri doğrultusunda ilgili kavramlara yönelik güncel yaşamdan senaryolar oluşturulmuştur. Öğretmen adaylarından GYİT'deki her bir senaryoyu dikkate alarak soru köklerine cevap vermeleri istenmiştir. GYIT'e ait örnek sorulardan birisi EK-2'de sunulmuştur.

GYİT'nin içerik analizinde, adayların verdikleri cevaplar doğrultusunda üç farklı kategori belirlenmiş ve her bir kategori puanlandırılmıştır. GYİT’nin analizi için araştırmacılar tarafından oluşturulan Rubrik-2 Tablo 2'de sunulmaktadır.

Tablo 2

GYİT'nin Analizine Yönelik Rubrik-2

\begin{tabular}{lcc}
\hline & Kategoriler & Puan \\
\hline Doğru cevap (D) & 2 \\
Yanlış cevap (Y) & 1 \\
Boş (B) & 0 \\
\hline
\end{tabular}


Adayların her bir test sorusu için verdikleri doğru cevap 2, yanlış cevap 1 puan olarak değerlendirilirken boş bırakılan cevaplar için 0 puan verilmiştir. $\mathrm{Bu}$ durumda öğretmen adaylarının GYİT'den alacağı en yüksek puan 14, en düşük puan ise 0'dır. Ayrıca adayların GYİT'de verdikleri doğru ve yanlış cevaplarına ait yüzdeler hesaplanarak tablolaştırılmıştır. Tabloların sunumunda, öğretmen adaylarının yanılgılı ifadeleri ve bunlara ait yüzde değerleri sergilenmeye çalışılmıştır.

Fen tutum ölçeği (FTÖ). Araştırmada, Demir (2005) tarafından öğretmen adayları için geliştirilen 5'li likert modelinde 40 maddelik fen tutum ölçeği aynen kullanılmıştır. Ölçekte kullanılan derecelendirme sistemi 5'li likert modeline göre 5 "Tamamen Katılıyorum", 4 "Katılıyorum", 3 "Kararsızım, 2 "Katılmıyorum" ve 1 "Hiç Katılmıyorum" şeklinde ifade edilmiştir. Ölçek; değer verme, ilgi, zevk alma, korkma ve özgüven olmak üzere 5 faktörlü bir ölçektir. Ölçeğin değer verme faktörü için 0.84 , ilgi faktörü için 0.80 , zevk alma faktörü 0.88 , korkma için 0.77 ve özgüven faktörü için 0.83 güvenilirlik katsayısı belirlenirken, ölçeğin tamamı için 0.82 güvenilirlik katsayısı tespit edilmiştir.FTÖ'nün analizinde, ölçekte bulunan olumlu ifadeler 5'den 1'e doğru, olumsuz ifadeler ise 1'den 5'e doğru puanlandırılmıştır. Bir adayın tutum ölçeğinden alabileceği en yüksek puan 200 , en düşük puan ise 40 'tır.

\section{İşlem Basamakları}

Araştırma Fen ve Teknoloji Laboratuar Uygulamaları-II dersi kapsamında yürütülmüştür. Haftada 2 saat olarak uygulanan derste, öğrencilere ilköğretim 5. Sınıf Öğretim Programında yer alan konular ve bu konuların kazanımlardan bir ya da birkaçı verilerek, etkinlik içerikli 20-30 dakikalık sunumlar yapmaları istenmiştir. Sunumlar sonrasında yapılan uygulamalar tartışılarak öğrencilerin konu ve alan bilgileri sorgulanmıştır. Dönem boyunca, öğrencilerin sunumları ve sunum sonrasındaki sorgulamaları araştırmacılar tarafindan alan notları tutularak gözlemlenmiştir. Yapılan gözlemlerde 5. Sınıf Fen ve Teknoloji Öğretim Programı ve ders kitaplarında yer alan anahtar kavramlar dikkate alınarak öğretmen adaylarının ilgili kavramlara ait güncel yaşam deneyimi sunabilme durumları sorgulanmıştır. Yapılan gözlemler sonrasında öğretmen adaylarının günlük yaşam ilişsilendirmelerinde sıkıntı duydukları kavramlar tespit edilmiş ve bu kavramlara yönelik öğretmen adaylarının nasıl bir kavram yanılgısı içerisinde oldukları sergilenmeye çalışılmıştır. Bu kapsamda ilgili kavramlara yönelik açık uçlu sorulardan oluşan veri toplama araçları geliştirilmiştir. Güncel yaşam ilişkisi kurmada zorlanılan kavramların tespiti ve bu kavramlara yönelik öğretmen adaylarının nasıl bir yanılgı içerisinde olduklarını belirleyebilmek için Fen Okuryazarlık Testi (FOYT) ve Güncel Yaşam İlişkilendirme Testi (GYIT) kullanılmıştır. FOYT ile fen okuryazarlık boyutlarından "Anahtar Fen Kavramları" boyutu sorgulanmıştır. Ayrıca öğrencilerin fen ve teknoloji dersine yönelik tutumlarını belirleyerek tutumları ile fen ve güncel yaşam ilişkilendirmeleri arasındaki ilişkiyi belirleyebilmek için Fen Tutum Ölçeği (FTÖ) kullanılmıştır. 


\section{Verilerin Analizi}

Yapılan çalışmada kullanılan FOYT, GYİT ve FTÖ’nün analizinde, araştırmanın amacı doğrultusunda tanımlayıcı istatik kullanılarak öğretmen adaylarının ilgili testlerden aldıkları puanların aritmetik ortalamaları ve standart sapmaları belirlenmeye çalışılmıştır. Ayrıca ilgili testlerden elde edilen puanlar arasındaki ilişkinin belirlenebilmesi için Pearson Korelasyon Katsayısı'na başvurulmuştur. Analiz esnasında elde edilen katsayının 0.00-0.25 aralığ1 çok zayıf, 0.26-0.49 aralığ1 zayıf, 0.50-0.69 aralığı orta, 0.70-0.89 aralığı yüksek ve 0.90-1.00 aralığı ise yüksek ilişkili olarak kategorilendirilmiştir. Ortaya çıkan bu değerin negatif değer taşıması durumunda negatif yönlü doğrusal bir ilişkiyi ifade ederken, pozitif değer taşıması durumunda pozitif yönlü doğrusal bir ilişkiyi ifade etmektedir (Kalaycı, 2008). Ayrıca, yapılan çalışma ile GYİT'den elde edilen ve öğrencilerin ilgili kavramlar üzerindeki doğru ve yanılgılı ifadeleri belirlenerek bu ifadelerin yüzdesel hesaplamaları yapılmıştır. İlgili tablolardaki doğru cevaplar "D", yanlıș cevaplar "Y" ve boş bırakılan cevaplar "B" ile simgelenmişlerdir.

\section{Bulgular ve Tartışma}

Çalışmanın birinci araştırma sorusu çerçevesinde, adayların fen okuryazarlıkları, fenne karşı tutumları ve günlük yaşam ilişkilendirmeleri arasındaki ilişki analiz edilmiştir. Öğretmen adaylarının FOYT, GYİT ve FTÖ’den almış oldukları puanlara yönelik istatistikî veriler Tablo 3’te sunulmaktadır.

Tablo 3

Öğretmen Adaylarının FOYT, GYİT ve FTÖ Testlerinden Almış Oldukları Puanlara Yönelik Istatistiki Veriler

\begin{tabular}{lccccc}
\hline DEĞIŞSENLER & $\mathrm{N}$ & Min. & Max. & $\mathrm{X}_{\text {ort. }}$ & ss \\
\hline FOYT & & 8 & 19 & 14.43 & 2.88 \\
GYİT & 200 & 4 & 12 & 6.51 & 1.49 \\
FTÖ & & 99 & 195 & 146.66 & 28.06 \\
\hline
\end{tabular}

Tablo 3'de görüldüğü gibi, öğretmen adayları fen okuryazarlık testinden en düşük 8, en yüksek 19 puan almışlardır. Adayların fen okuryazarlıkları testine ait aritmetik ortalamaları, 14.43 olarak tespit edilmiştir. Öğretmen adayları günlük yaşam ilişkilendirme testinden ise en düşük 4, en yüksek 12 puan almışlardır. Adayların günlük yaşam ilişkilendirmesi testine ait aritmetik ortalamaları, 6.51 olarak tespit edilmiştir. Araştırmanın bir diğer değişkeni olan fenne karşı tutum anketinden ise öğretmen adayları en düşük 99, en yüksek 195 puan almışlardır. Adayların fenne karş1 tutumlarının aritmetik ortalaması, 146.66 olarak tespit edilmiştir.

Çalışmanın birinci araştırma sorusu çerçevesinde, öğretmen adaylarının fen okuryazarlıkları, fen tutumları ve fen bilgilerini günlük yaşama aktarabilmeleri 
arasındaki ilişkinin boyutu Pearson Korelasyon Katsayısı ile ölçülmeye çalışılmış ve sonuçlar Tablo 4'te sunulmuştur.

Tablo 4

Öğretmen Adaylarının Fen Okuryazarlıkları, Fen Tutumları ve Günlük Yaşam İlişkilendirmeleri Arasındaki İlişkiye Dair Pearson Korelasyon Katsayısı Sonuçları

\begin{tabular}{lccc}
\hline DEĞIŞKENLER & $\mathrm{N}$ & $\mathrm{r}$ & $\mathrm{p}$ \\
\hline FOYT - FTÖ & & 0.58 & $.000^{*}$ \\
FOYT - GYIT & 200 & 0.32 & $.001^{*}$ \\
FTÖ - GYİT & & 0.47 & $.000^{*}$ \\
\hline
\end{tabular}

$\left({ }^{*} p<0.01\right.$ istatistiksel olarak anlamlı bir ilişki vardır. $)$

Tablo 4 incelendiğinde, öğretmen adaylarının fen okuryazarlıkları ve fenne karşı tutumları arasında orta düzeyli, pozitif yönlü ve anlamlı bir ilişkinin olduğu görülmüştür $(\mathrm{r}=0.58 ; \mathrm{p}=0.000, \mathrm{p}<0.01)$. Adayların fen okuryazarlıkları ile günlük yaşam ilişkilendirmeleri arasında zayıf, pozitif yönlü ve anlamlı bir ilişkinin olduğu tespit edilmiştir $(r=0.32 ; p=0.001, p<0.01)$. Öğretmen adaylarının fenne karşı tutumları ile günlük yaşam ilişkilendirmeleri arasında ise zayıf, pozitif yönlü ve anlamlı bir ilişkinin olduğu görülmektedir $(r=0.47 ; p=0.000, p<0.01)$. Adayların fen okuryazarlıkları ile birlikte fenne karşı tutumlarının günlük yaşam ilişkilendirmelerini zayıf bir şekilde desteklediği görülse de; ilişki değerleri incelendiğinde, tutumun fen okuryazarlığına göre daha etkili olduğu söylenebilir. Oysa, McCann (2001) fen okuryazarlığı gelişmiş olan bireylerin fene ait bilgilerini güncel yaşama daha kolay aktardığını ileri sürmektedir. Bu durum, çalışmada kullanılan kavramların özellikle kavram yanılgısına düşülen kavramlar olmasından ve sınırlı sayıda kavram üzerinden fen okuryazarlıklarının belirlenmeye çalışılmasından kaynaklanmış olabilir.

Çalışmanın ikinci araştırma sorusu çerçevesinde, öğretmen adaylarına GYİT uygulanmış ve öğretmen adaylarının günlük yaşam ilişkilendirmelerine yönelik yanılgıları incelenmiştir. GYİT'te öğretmen adaylarına ilgili kavramla ilgili günlük yaşamdan senaryolar verilmiş ve bu senaryolara bağlı olarak soru kökleri sunulmuştur. Öğretmen adaylarının GYİT'in her bir sorusu için vermiş oldukları doğru ve yanlış cevapların yüzdeleri ile birlikte yanılgılı ifadeleri tablolar halinde sunulmuştur.

Testin birinci sorusuna ait soru kökünde, öğrencilere " $100{ }^{\circ} \mathrm{C}$ ve $10{ }^{\circ} \mathrm{C}$ sicaklıktaki birer bardak sudan hangisinin daha çabuk donacağı sorulmuş ve nedeninin açıklanması" istenmiştir. Öğretmen adaylarının bu soruya verdikleri cevaplar doğrultusunda oluşturulan kategorilere ait yüzdeler Tablo 5’te sunulmuştur. 
Tablo 5

Birinci Soruya Verilen Öğrenci Cevaplarına Ait Yüzdeler

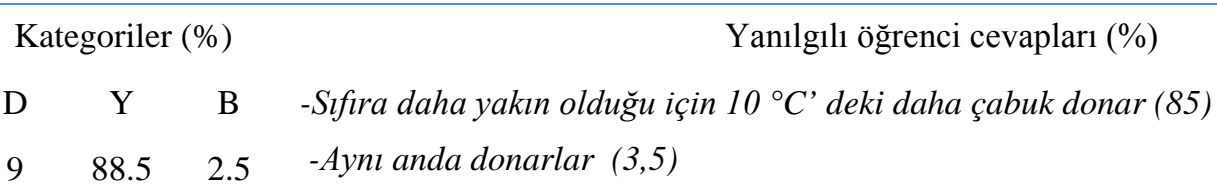

Tablo 5 incelendiğinde, öğretmen adaylarının \%88.5 oranında bu soruyu yanlış cevapladıkları görülmektedir. Öğretmen adaylarından, “100 ${ }^{\circ} \mathrm{C}$ sicaklıkta bulunan sudaki buharlaşma nedeni ile madde kaybının daha hızlı olduğu ve bu madde kaybına bağlı olarak $100{ }^{\circ} \mathrm{C}$ suyun bulunduğu bardaktaki donmanın daha hızl gerçekleşeceği”" görüşünü ifade etmeleri beklenirken, öğretmen adaylarının madde kaybını dikkate almadan soruyu cevapladıkları görülmektedir. Adayların, $10^{\circ} \mathrm{C}$ 'deki suyun sıfıra yakın olması nedeniyle daha çabuk donacağını belirtmeleri, günlük bilgileri doğrultusunda kendilerince mantıklı bir açıklama yaptıkları şeklinde yorumlanabilir. Kavram yanılgılarının nedenini açıklamaya çalışan parçalı yapılandırma görüşü de, bireylerin günlük deneyimlerinden basit çıkarımlar (olgusal ilkel düşünceler/ phenemonological primitives) yaparak kavram yanılgıları oluşturabildiklerini desteklemektedir (Chi, 2005).

Testin ikinci sorusuna ait soru kökünde, öğrencilere "makarna pişirirken tuzu ne zaman attıkları gerekçesi ile birlikte sorulmuştur”. Öğretmen adaylarının bu soruya verdikleri cevaplara ait yüzde değerleri Tablo 6'da verilmiştir.

Tablo 6

İkinci Soruya Verilen Öğrenci Cevaplarına Ait Yüzdeler

\begin{tabular}{|c|c|c|c|}
\hline \multicolumn{3}{|c|}{ Kategoriler (\%) } & Yanılgılı öğrenci cevapları (\%) \\
\hline \multirow[t]{3}{*}{$\mathrm{D}$} & $\mathrm{Y}$ & B & $\begin{array}{l}\text {-Tuz kaynamış suda daha çabuk çözünür ve etrafa daha çok yayılır, bu nedenle } \\
\text { kaynadıktan sonra atarız }(7,5)\end{array}$ \\
\hline & & & -Suyun daha çabuk kaynaması için, su kaynamadan atılır (7) \\
\hline & & & -Kaynamaya başladığında atılır ki, tuz daha çabuk çözünür, erir (5) \\
\hline \multirow[t]{2}{*}{65,5} & 32 & 2,5 & $\begin{array}{l}\text {-Kaynamaya başladığında atılır ki, ısı kaybından dolayı tuzun bir kısmı } \\
\text { buharlaşmaz böylece tuzun tadı kaybolmaz }(2,5)\end{array}$ \\
\hline & & & $\begin{array}{l}\text {-Makarnayı süzdükten sonra atarız ki tuzun tadı kalsın böylece daha az tuz } \\
\text { kullanmış oluruz (2) }\end{array}$ \\
\hline
\end{tabular}

Tablo 6'da görüldüğü gibi öğretmen adaylarının \%65.5'i bu soruya doğru cevabı verirken \%32'si yanlış gerekçe belirtmiştir. Öğretmen adaylarından, “tuzun kaynama noktasını yükselteceği ve bu nedenle daha fazla enerji harcanmasına sebep olacă̆l için kaynama öncesinde atılması gerektiği" görüşünü ifade etmeleri beklenirken, öğretmen adaylarının bir kısmının bu durumu dikkate almadığı görülmektedir. Öğretmen adaylarının gerekçeleri incelendiğinde, büyük çoğunluğunun daha iyi çözünmesi, etrafa 
dağılması ve tadını vermesi için su kaynadıktan sonra tuzun atılması gerektiğini ifade etmişlerdir. Adayların bu açıklamaları dikkate alındığında, bilimsel dayanağı olan açıklamalardan çok günlük deneyimlerine dayanan yorumlar yaptıkları görülmektedir. Öğretmen adaylarının bir kısmının ise, “önceden atılan tuzun suyun kaynamasını hızlandırdı̆̆ııı (\%1)" belirtirken, bazıları da "makarnaların dă̆lmaması ve sertleşmemesi, daha lezzetli olması için kaynamaya başladı̆̆ında atılması gerektiğini (\%1)" belirtmişlerdir. Ayrıca, "...su ile tuz birbirine daha iyi karışsın diye su kaynamaya başladığında atılır...”, “...tuz makarnalar tarafindan daha çabuk emilsin diye kaynadıktan sonra atarız...”, “...su kaynadıktan sonra atarız ki tuz eriyip gitmesin ve etkisi kaybolmasın, tuzun kaynamış suda yoğunluğu az olacağından daha çabuk erir, bu nedenle kaynadıktan sonra atarız...” gibi yanılgılı görüşlere de rastlanmıştır.

Elde edilen bulgulardan, öğretmen adaylarının kaynama ile birlikte tuzun daha çabuk çözünebileceğini ve kaynama suyuna atılarak tadlandırma sağlayacağı üzerine durdukları görülmüştür. Öğretmen adaylarının bir çoğunun tuzun kaynama noktasını artırabileceği noktasındaki görüşlerine rağmen, ilgili bilgiyi kullanmamaları, öğretmen adaylarının bilimsel bilgileri sadece ders bağlamında kullanmaya çalışıyor olmalarından kaynaklanabilir. $\mathrm{Bu}$ durum, öğretmen adayının ders bağlamında öğrenmiş oldukları kavramları günlük yaşam esnasında farklı bir duruma uyarlamada sorunlar yaşamasına neden olabilir. Yani, öğretmen adayı ders süreçlerinden elde edindiği bilgiler ile günlük yaşam deneyimlerinden edindiği bilgileri bağımsız bir şekilde değerlendiriyor olabilir. Halim ve Meerah (2002) de öğrencilerin problemlere yönelik çözüm üretmede bilimsel bilgilerden ziyade deneyimlerine başvurduklarını ileri sürerek bu durumu desteklemektedirler. Çalık ve Ayas (2005) ise bilimsel bilgiyi kullanan öğrencilerin, konuya yönelik ilke ve genellemeleri tam olarak kavramadan mevcut bilgi düzeyleri üzerinden basit düşünerek yorumlar yaptıklarını ve bu durumun kavram yanılgılarının oluşmasına neden olduğunu ileri sürmektedir. Elde edilen bulgular da gösteriyor ki, öğretmen adayları kaynamayı etkileyen faktörler ve bu faktörleri açıklayan ikincil kavramlar üzerinde ilişki kuramamakta ve günlük yaşam deneyimlerine yönelik basit yorumlarla olay ve olguları açıklamaya çalışmaktadırlar.

Testin üçüncü sorusuna ait soru kökünde, öğrencilere "kaynayan suya daldırılan bir cam termometrenin seviyesinin önce bir miktar düşü̆̈̈̈ ve sonra yükselmeye başladı̆̆ belirtilerek gerekçesinin açıklanması" istenmiştir. Öğretmen adaylarının cevaplarına ait yüzde oranları Tablo 7'de sunulmuştur. 


\section{Tablo 7}

Üçüncü Soruya Verilen Öğrenci Cevaplarına Ait Yüzdeler

\begin{tabular}{|c|c|c|c|}
\hline \multicolumn{3}{|c|}{ Kategoriler (\%) } & Yanılgılı öğrenci cevapları (\%) \\
\hline $\mathrm{D}$ & $\mathrm{Y}$ & B & \multirow{2}{*}{$\begin{array}{l}\text {-Isı alış verişi nedeniyle termometrenin seviyesi bir miktar düşer sonra suyun } \\
\text { sıcaklığına göre yükselir (36) }\end{array}$} \\
\hline \multirow{7}{*}{3} & \multirow{7}{*}{76} & \multirow{7}{*}{21} & \\
\hline & & & -Termometre soğuk olduğu için önce kendi ısınır, sonra sıcaklı̆̆l yükselir (14) \\
\hline & & & -Termometre sıcaklığını bir süre korur, çünkü suyun ısısını hemen hissedemez ama \\
\hline & & & alıştıktan sonra ısısı yükselmeye başlar (6) \\
\hline & & & -İçindeki civanın kaynama noktasından dolayı (6) \\
\hline & & & -Termometre önce kendi sıcaklığını sabitler sonra suyun sıcaklığını ölçer (3) \\
\hline & & & -Kaynayan suyun sıcaklığı sabittir, bu sebeple başlangıçta termometrenin ısısı \\
\hline
\end{tabular}

Tablo 7 incelendiğinde, öğretmen adaylarının ancak \%3’ünün doğru cevab1 verdiği, \%76'sının ise yanlış gerekçe belirttiği görülmektedir. Öğretmen adaylarından, "kaynayan suya atılan cam termometredeki ani ısı değişikliği ile genleşmenin oluşacağ ve bu genleşmeye bağll olarak önce civa seviyesinin bir miktar aşağıya düşüp daha sonar yükselmeye başlayacă̆g” görüşünü ifade etmeleri beklenirken, öğretmen adaylarının çok büyük bir kısmının genleşmeyi dikkate almadığı görülmektedir. Öğretmen adaylarının çoğunluğu sıcaklık farklılığından doğan bir düşüş ve artış olduğunu belirtmişlerdir. Adayların bazılarının bu durumu açıklayabilmek için kendilerince basit yorumlar yaptıkları da dikkat çekmektedir. Ayrıca öğretmen adayları, “...kaynayan su cıvayı eritir seviye düşer, sonra genleşmeye başlayınca seviye artar...”, “...soğuk suyla karşılaşan slcak termometrede ters tepki olur bu sebeple derecesi düşer...”, “...kaynayan sıv termometreye ters bir kuvvet uygular, kuvvetin etkisine alışınca isı normale döner ve yükselir...”, “...kaynayan su termometreye bir basınç uygular, termometre bu basıncı dengelemeye çalışır ve isısı düşer sonra suyun sıcaklığını ölçer...”, “...termometrenin bulunduğu ortam suya göre soğuktur. Termometre suya atıldı̆̆ında suyun dibi yüzeye göre daha düşük ısıdadır, çünkü kaynama yüzeyde olur. Bu sebeple termometrenin seviyesi önce düşer sonra yükselir..." gibi yanlış açıklamalar da yapmaktadırlar. Bu açıklamalar, ilgili senaryo kapsamında öğretmen adaylarının daha çok ısı ve sıcaklık kavramına odaklandıklarını ve genleşme durumunu ihmal ettiklerini ortaya koymaktadır. $\mathrm{Bu}$ durum, öğretmen adaylarının bilimsel kavramları birbirinden bağımsız düşünerek kavramlar arasında ilişki kuramamalarından kaynaklanabilir. Berg ve Brouwer (1991) de fene ait birbirine yakın kavramların öğrenciler tarafından birbirinden bağımsız düşünülüp, bütüncül olarak değerlendirilemediği için ihmal edildiğini ileri sürmektedirler. Özetle, öğretmen adayları ilgili kavrama ait ikincil kavramları ihmal ettiği gibi bazen de ikincil kavramlara odaklanarak ana kavramı ihmal edebilmektedirler. Yapılan çalışmada da görülmektedir ki, öğretmen adayları yapmış oldukları açıklamalarda, genleşmeyi etkileyen faktörleri ön plana çıkarırken bu faktörlere bağlı olarak gelişen genleşme kavramını ihmal etmektedirler. 
Testin dördüncü sorusuna ait soru kökünde, öğretmen adaylarından "böbreklerimiz dışında metabolizma atıklarının vücudumuzdan atılmasını sağlayan yapı ve organları yazmaları" istenmiştir. Öğretmen adaylarının bu soruya verdikleri cevaplara ait yüzdeler Tablo 8’de verilmiştir.

Tablo 8

Dördüncü Soruya Verilen Öğrenci Cevaplarına Ait Yüzdeler

\begin{tabular}{|c|c|c|c|}
\hline \multicolumn{3}{|c|}{ Kategoriler (\%) } & \multirow{3}{*}{$\begin{array}{l}\text { Yanılgılı öğrenci cevapları (\%) } \\
\text {-ídrar borusu, idrar kesesi, idrar kanalı (28) } \\
\text {-Bağırsak, deri (10) }\end{array}$} \\
\hline $\mathrm{D}$ & $\mathrm{Y}$ & $\mathrm{B}$ & \\
\hline \multirow{3}{*}{44} & \multirow{3}{*}{56} & \multirow{3}{*}{0} & \\
\hline & & & -Bă̆ırsak, akciğer, deri (8) \\
\hline & & & -Kalın bă̆ırsak+ince bă̆ırsak (6) \\
\hline
\end{tabular}

Tablo 8'de görüldüğü gibi öğretmen adaylarının \%28'i, boşaltım sisteminde bulunan böbrek dışındaki yapıları belirtmiş, \%24'ü ise bağırsakların metabolizma atıklarının dışarı atılmasından sorumlu olduğunu yazmışlardır. $\mathrm{Bu}$ durum öğretmen adaylarının sindirim atıklarının elimine edilip vücuttan atılmasını da boşaltım olarak nitelendirdiklerini göstermektedir. Öğrencilere göre "metabolizma atıkları" ve "sindirim atıkları" vücuttan atıldıkları için "boşaltım" olarak nitelendirilmektedir (Güngör ve Özgür, 2009). Oysaki boşaltım atıkları, karbondioksit, idrar ve ter olarak uzaklaştırılırken sindirim atığı dışkı olarak atılmaktadır. Öğrencilerin \%2'si ise kulaktan kulak sıvısının, burundan mukusun, gözden gözyaşının dışarı atıldığını yazmış ve ayrıca tükürük ve anüsü de boşaltım sisteminin bir parçası olarak ifade etmişlerdir. Bu durum, bilimsel dil ile günlük dilin birbirine karışmış olmasından kaynaklanabilir. Güneş (2010)'a gore günlük dilde bazı kavramlar bilimsel olmayan bir şekilde birbiri yerine kullanılmaktadır. Yapılan çalışmada da sindirim ve boşaltım kavramlarının sıkça birbirinin yerine kullanıldığı ve deri, akciğer gibi metabolizma atıklarının uzaklaştırıldığı organlar yerine, sindirim organlarının cevap olarak verildiği görülmektedir.

Testin beşinci sorusuna ait soru kökünde, öğretmen adaylarından "sindirim kanalını oluşturan yapı ve organları sırasıyla yazarak, besinlerin kana karıştığ organın altını çizmeleri” istenmiştir. Öğretmen adaylarının bu soruya verdikleri cevaplara ait yüzdeler Tablo 9'da verilmiştir. 
Tablo 9

Beşinci Soruya Verilen Öğrenci Cevaplarına Ait Yüzdeler

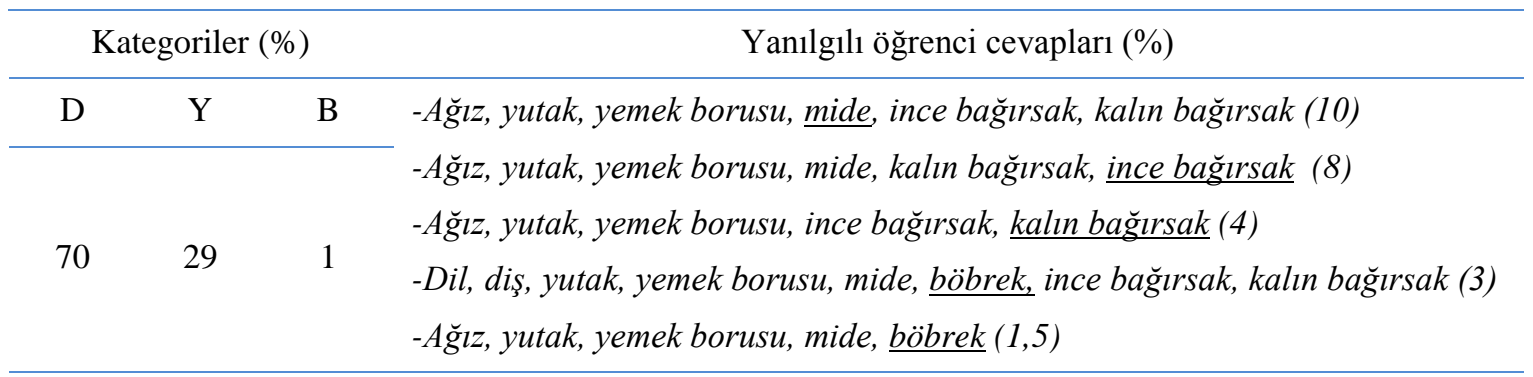

Tablo 9 incelendiğinde, öğretmen adaylarının \%29'unun bir kısmının sindirim sistemi organlarının sırasını doğru yazamadıkları; bir kısmının ise sindirilen besinlerin kana karıştığı organı yanlış belirttikleri görülmektedir. Öğretmen adaylarından, sindirim organlarını yazmaları ve besinlerin kana karıştığı organı "ağlz, yutak, yemek borusu, mide, ince bă̆ırsak ve kalın bağırsak" şeklinde ifade etmeleri beklenirken, öğretmen adaylarını bir kısmının yanlış cevaplar verdikleri tespit edilmiştir. Öğretmen adaylarının, özellikle besinlerin böbrekler aracılığıyla kana karıştığını ifade etmeleri, sindirim sistemi ile boşaltım sistemi arasında yanılgılı durumlar yaşadıklarını ortaya koymaktadır. Güngör ve Özgür (2009), ilköğretim kademesinde yürüttükleri çalışmalarında, öğrencilerin sindirim kanalını, mideden böbreğe geçiş şeklinde ve böbrek ile bağırsakları bağlantılı olarak çizdiklerini; sindirim sistemi organlarının idrar kesesi ile bittiğini gösterdiklerini ortaya koymuşlardır. Aynı yanılgılı durumun yüksek öğretim düzeyinde de görülüyor olması, ilgili yanılgının oldukça kökleşmiş ve değişime direnç gösteren bir yanılgı olduğunu ortaya koymaktadır.

Testin altınc1 sorusuna ait soru kökünde ise öğretmen adaylarından 1sı ve sıcaklık kavramını karşılaştırabilecekleri bir senaryo verilmiş ve bu senaryo içerisinde öğretmen adaylarından (1) “hissedilen sicaklık” kavramını tanımlamaları ve (2) "klşın neden koyu renkli giysileri tercih etmemiz gerektiği"ni açıklamaları istenmiştir. Öğretmen adaylarının "hissedilen sicaklık” kavramına yönelik cevapları Tablo 10' da yer alırken, "kışın neden koyu renkli giysileri tercih etmemiz gerektiği”"ne yönelik görüşleri Tablo 11'de sunulmuştur. 


\section{Tablo 10}

Altıncı Soruya (1) Verilen Öğrenci Cevaplarına Ait Yüzdeler

\begin{tabular}{|c|c|c|c|}
\hline \multicolumn{3}{|c|}{ Kategoriler (\%) } & Yanılgılı öğrenci cevapları (\%) \\
\hline $\mathrm{D}$ & $\mathrm{Y}$ & B & -Termometreye bakmadan derimizin algıladiğı sıcaklıktır (10) \\
\hline \multirow{13}{*}{25} & \multirow{13}{*}{72,5} & \multirow{13}{*}{2,5} & -Isıdır. Ne kadar sıcaklık olursa, o kadar ısı oluşur (8) \\
\hline & & & $\begin{array}{l}\text {-Ütü yaparken kıyafetimize ısı geçer, elimizi kıyafetimize koyduğumuzda } \\
\text { sıcaklığını anlarız. Yani temas yüzeyi sonucunda dokunma ile anlaşılan } \\
\text { sıcaklık(8) }\end{array}$ \\
\hline & & & -Bizim hissettiğimiz sıcaklıktır $(6,5)$ \\
\hline & & & -Isının insanlar üzerindeki etkisidir, kimi aynı ısıda üşür kimi terler \\
\hline & & & (6) \\
\hline & & & -Yerkürede güneş ışınlarının gelmesiyle oluşan sıcaklı̆̆ıdır (5) \\
\hline & & & -Sicak olan bir maddeden soğuk olana geçen enerjidir (5) \\
\hline & & & -Termometre ile ölçülen ısıdır (5) \\
\hline & & & -O yöredeki istasyonların ifade ettiği sıcaklık (4) \\
\hline & & & $\begin{array}{l}\text {-Vücut ısımızın bulunduğumuz ortamın sıcaklığına göre değişim } \\
\text { göstermesidir (4) }\end{array}$ \\
\hline & & & -Sıcaklığın derecesinin hissedilebilecek kadar fazla olmasıdır (4) \\
\hline & & & -Havanın o andaki tahmini sıcaklığıdır, bir anda değişebilir (4) \\
\hline & & & $\begin{array}{l}\text {-Dışarıdaki sıcaklığın soğuk insan vücuduna teması ile terleme olur bu } \\
\text { hissedilen sıcaklıktır (3) }\end{array}$ \\
\hline
\end{tabular}

Tablo 10'da görüldüğü gibi öğretmen adaylarının \%25'i bu soruya doğru cevap verirken, \%72,5'i kavramı yanlış tanımlamışlardır. Öğretmen adaylarının bu soruda, "hissedilen sicaklı" kavramını insanın kendi hissettiği sıcaklık ya da termometrenin okuduğu değer olarak açıkladıkları ve 1sı ile sıcaklık kavramını birbirlerinin yerine kullandıkları (McDermot, 2003) görülmektedir. Öğretmen adaylarının bir kısmının yapmış olduğu açıklamalarda sıcaklığı da 1sı gibi bir tür enerji olarak algıladığı görülmektedir. 


\section{Tablo 11}

Altıncı Soruya (2) Verilen Öğrenci Cevaplarına Ait Yüzdeler

\begin{tabular}{|c|c|c|c|}
\hline \multicolumn{3}{|c|}{ Kategoriler (\%) } & \multirow{3}{*}{$\begin{array}{l}\text { Yanılgılı öğrenci cevapları (\%) } \\
\text {-Açık renkli giysiler ışığı iter, koyu renkliler ise ışığı çeker (10) } \\
\text {-Koyu renkli giysiler ısıyı çeker (8) }\end{array}$} \\
\hline $\mathrm{D}$ & $\mathrm{Y}$ & B & \\
\hline \multirow{14}{*}{35} & \multirow{14}{*}{65} & \multirow{14}{*}{0} & \\
\hline & & & -Koyu renkli giysiler uslyı daha çok çeker (8) \\
\hline & & & $\begin{array}{l}\text {-Dışarıdan gelen ışınları daha fazla üzerimize çekmek, dolayısıyla daha fazla } \\
\text { ısınmak (8) }\end{array}$ \\
\hline & & & -Koyu renkli giysiler sıcak havayı daha çok emer (4) \\
\hline & & & -Koyu renkli giysiler sıcaklı̆̆ içeri geçirir ve bizi sıcak tutar (4) \\
\hline & & & -Soğuk havayı daha az hissetmek için (2) \\
\hline & & & $\begin{array}{l}\text {-Kışın hava kapalı olduğu için beyaz ışık ortamda hâkimdir. Ĕger açık renk } \\
\text { giyersek zıtlık sağlanamadığından fark edilmek zor olur ve göz yorulur (2) }\end{array}$ \\
\hline & & & $\begin{array}{l}\text {-Kışın hava bulutlu ve yağmurlu olur, açık renkli elbiseler daha çok fark edilir, } \\
\text { abes olur (2) }\end{array}$ \\
\hline & & & -Koyu renkli giysiler ışı̆̆ı ve ısıyı kendine çeker (2) \\
\hline & & & -Soğuk renkli giysiler soğuk havalarda daha sıcak tutar (2) \\
\hline & & & -Koyu renkler ısıyı çabuk kaybetmez, içine hapseder (4) \\
\hline & & & -Koyu renkler gözü yormaz, ışı̆ğ daha iyi yansıtır (1) \\
\hline & & & -Koyu renkli giysiler güneşi çeker ve sıcak tutar (1) \\
\hline & & & -Güneş koyu renkleri kendine çeker (1) \\
\hline
\end{tabular}

Tablo 11 'de görüldüğü gibi öğretmen adaylarının \%35'i bu soruya doğru cevap verirken, \%65'i yanlış açıklama yapmıştır. Öğrencilerin açıklamaları incelendiğinde, "1şığı emilmesi”" yerine "1şı̆̆ın çekilmesi" ifadesinin kullanıldığı dikkat çekmektedir. Öğrencilerin büyük çoğunluğunun koyu renkli giysilerin 1sıyı ve 1şığı kendisine çektiği inanışına sahip oldukları görülmektedir.

Testin yedinci sorusuna ait soru kökünde, öğretmen adaylarına “-10 ${ }^{\circ} \mathrm{C}$ deki bir buz parçasının bir behere konup, ispirto ocă̆ına yerleştirilerek su kaynayana kadar ısı verildiği belirtilmiş ve bu süreci gösteren slcaklık-zaman grafiğini çizmeleri" istenmiştir. Öğretmen adaylarının bu soruya verdikleri cevaplara ait yüzde oranları Tablo 12'de sunulmuştur.

Tablo 12

Yedinci Soruya Verilen Öğrenci Cevaplarına Ait Yüzdeler

Kategoriler (\%)

\begin{tabular}{ccc}
\hline D & Y & B \\
25.5 & 59 & 15.5 \\
\hline
\end{tabular}


Tablo 12 incelendiğinde, öğretmen adaylarının \%25.5'inin doğru grafik çizimi yaptığı görülürken \%59'unun ise yanlış grafik çizimi yaptığı tespit edilmiştir. Öğretmen adaylarının \%15.5'i ise soruyu boş bırakmışlardır. Öğretmen adaylarının büyük ornda yanlış grafik çizmeleri, konuya ait bilgi eksikliğinden kaynaklandığı gibi grafik çizebilme becerilerinden de kaynaklanmış olabilir. Öğretmen adaylarının çizmiş olduğu yanlış grafik örnekleri Tablo13’te sunulmuştur.

Tablo 13

Yedinci Soruya Ait Yanlış Grafik Çizimleri

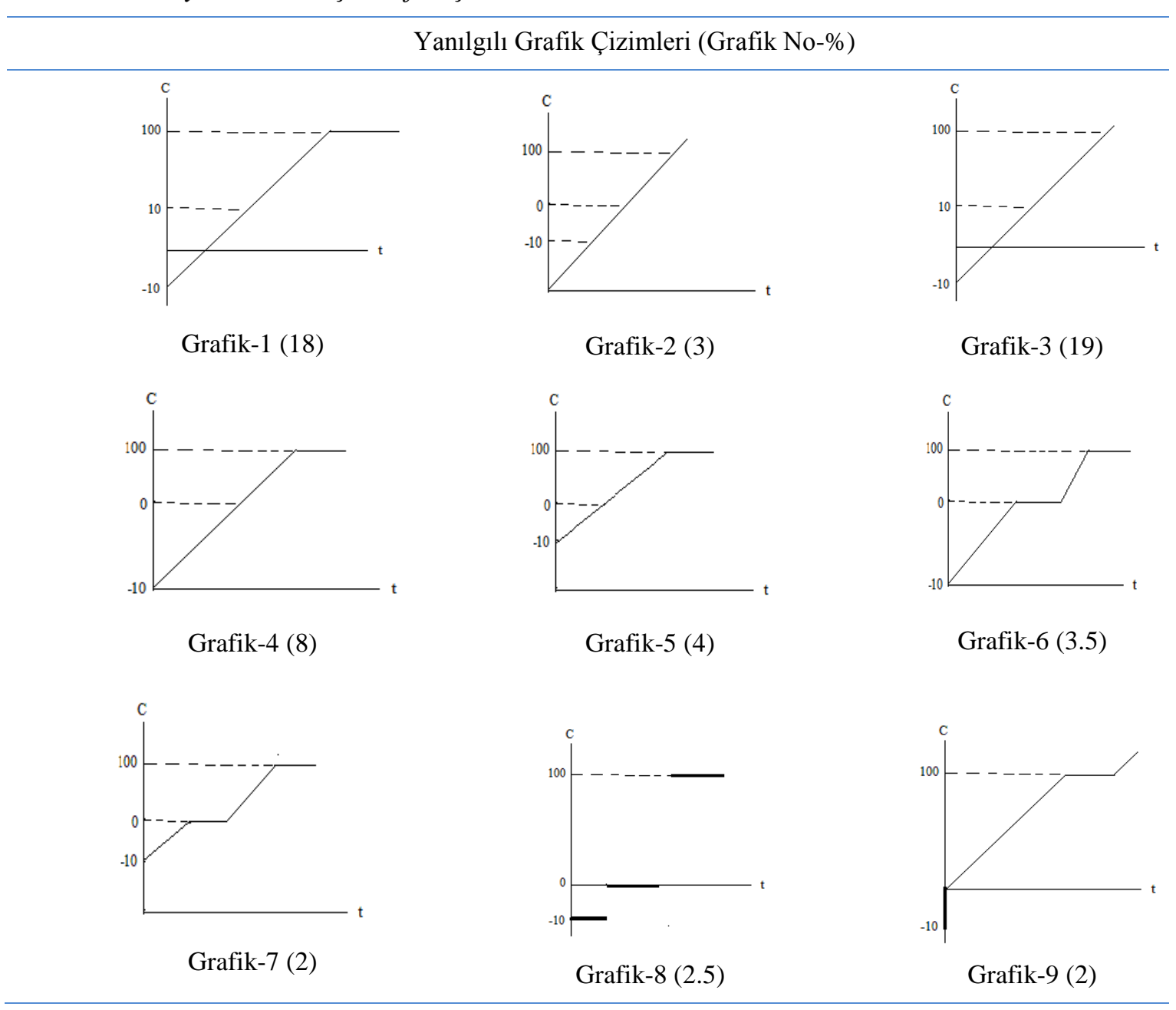

Öğretmen adaylarının grafikleri incelendiğinde, donma ve erime sürecindeki faz değişimlerinin genellikle ihmal edildiği görülmektedir (Grafik 1-2-3-4-5-9). Ayrıca öğretmen adaylarının koordinat sisteminin gösterimi konusunda da sıkıntılar yaşadı̆̆ 1 tespit edilmiştir (Grafik 2-4-5-6-7). Hal değişimi sırasında meydana gelen olayların öğrenciler tarafından tam olarak anlaşılmadığı belirtilmektedir (Çepni, Bayraktar, Yeşilyurt ve Coştu, 2001). Öğrenci grafiklerindeki yanlışlarda bu durumu destekler niteliktedir. 


\section{Sonuç ve Öneriler}

1. Öğretmen adaylarının fen bilgilerini günlük yaşamda kullanma durumları, öğretmen adayının fen okuryazarlığı ve fene karşı tutumuyla doğrudan ilişkilidir. Özellikle fene karşı olan tutumlar, öğretmen adayının fen bilgilerini günlük yaşam deneyimlerinde kullanma durumunu fen okuryazarlığına göre daha fazla etkilemektedir. Özetle, öğretmen adaylarının günlük yaşam deneyimleri sırasında fen bilgilerini kullanabilme durumları, bilişsel süreçlerin yanında duyuşsal süreçlerle de ilgili bir durumdur.

2. Öğretmen adayları sindirim-boşaltım ve 1s1-sıcaklık kavramlarını daha çok birbirinin yerine kullanarak kavram yanılgısına düşmektedirler. Bu durum, bilimsel dil ile günlük dilin birlikte kullanılmasından kaynaklanmaktadır. Özellikle günlük yaşam deneyimleri sonucunda elde edilen bilgileri özümsemeye meyilli olan öğretmen adayları günlük yaşamda kullandıkları dili bilimsel dil olarak kullanmaya çalışmakta ve bu durum yanılgıya düşmelerine sebep olmaktadır

3. Yapılan çalışmadan elde edilen bulgular ve literatür, sindirim-boşaltım ve 1s1sıcaklık kavramlarının birbiri yerine kullanılma durumunu ilköğretim çağından yüksek öğretime kadar her kademede görülebildiğini ortaya koymaktadır. Bu durum, ilgili yanılgının oldukça kökleşmiş ve değişime direnç gösteren bir yanılgı olduğu sonucunu doğurmaktadır.

4. Öğretmen adayları kaynama, erime, donma ve genleşme gibi kavramlarda ise parçalı yapılandırma görüşünün bir sonucu olarak kavram yanılgısına düşmektedirler. Öğretmen adayları, bu kavramlar ve bu kavramları etkileyen ikincil kavaramları birbirinden bağımsız düşünmekte ve kavramlar arasında ilişki kuramamaktadırlar. Bu durum, güncel yaşamda sıkça karşılaştığımız ve ilke ve genellemelerle açıklayabileceğimiz pek çok olay ve olgunun anlamlandırılamamasına sebep olarak, öğretmen adaylarının olay ve olgulara bütüncül bakış açısı ile yaklaşımını engellemekte ve günlük yaşam deneyimleri sırasında fen bilgilerini kullanırken basit çıkarımlar yapmalarına neden olmaktadır. Bu nedenle öğretmen adayları kavramlar hakkında doğru tanımlar yaparlarken, bu kavramların günlük yaşamdaki karşılıklarını bulmada ve bu bilgileri kullanmada sorunlar yaşamaktadırlar.

$\mathrm{Bu}$ sonuçlar doğrultusunda, adayların öğretmen olduklarında fen konularını öğrencilerine sevdirebilmeleri ve öğretebilmeleri için günlük yaşamdaki kullanım alanlarından haberdar olmaları gerekmektedir. Bu bağlamda, özellikle fen öğretimine yönelik derslerin öneminin öğrencilere daha iyi kavratılması ve dersin yürütülme sürecine öğrencilerin bütününün katılım göstermesine dikkat edilmelidir. Katılımların özellikle uygulama ağırlıklı, araştırma ve sorgulamaya dayalı, örnek olaylar üzerinden bütüncül yaklaşımın sergilendiği ve güncel yaşam ilişkilendirmelerinin kurulduğu ortamlarda gerçekleştirilmesi önerilmektedir. Bundan sonra yapılacak çalışmalar için, bahsi geçen ortamın kurularak bu ortamın kavram yanılgıları ve güncel yaşam deneyimleri üzerindeki etkisi araştırılabilir. 


\section{Kaynakça}

Anagün, Ş.S., Ağır, O. \& Kaynaş, E. (2010). İlköğretim öğrencilerinin fen ve teknoloji dersinde öğrendiklerini günlük yaşamlarında kullanım düzeyleri. 9. Ulusal Sınıf Öğretmenliği Eğitimi Sempozyumu Bildiriler Kitabı (s.329-334). Elazığ: Fırat Üniversitesi Yayınları.

Andrée, M. (2003). Everyday-life in the science classroom: A study on ways of using and referring to everyday-life. Paper presented at the ESERA Conference. Noordwijkerhout, Netherlands.

Atasoy, Ş. \& Akdeniz, A. R. (2005). Newton'un hareket kanunları ile ilgili öğretmen adaylarının sahip oldukları kavram yanılgıları. XIV. Ulusal Eğitim Bilimleri Kongresi Bildiriler Kitab1 (s.544-551). Denizli.

Ayas A., Coştu B. \& Ünal S. (2007). Günlük yaşamdaki olaylarin fen bilimleri öğretiminde kullanilmasi. Ahi Evran Üniversitesi (KEFAD), 8(1), 197-207.

Aydın, A. (2000). Gelişim ve Öğrenme Psikolojisi (2. baskı). Ankara: Alfa Yayınları.

Balım, A.G., Sucuoğlu, H. \& Aydın, G. (2009). Fen ve teknolojiye yönelik tutum ölçeğinin geliştirilmesi, Pamukkale Üniversitesi Eğitim Fakültesi Dergisi, 1(25), 33-41.

Baumert, J., Bos, W. \& Lehmann, R. (2000). TIMSS/III: Dritte Internationale Mathematik-und Naturwissenschaftsstudie. Opladen: Leske \& Budrich Press.

Berg, T. \& Brouwer, W. (1991). Teacher awareness of student alternate conceptions about rotational motion and gravity. Journal of Research in Science Teaching, 28, 3-18.

Black, P. \& Atkin, J.M. (1996). Changing the subject: Innovations in science, mathematichs and technology educations. London: Routledge in association with OECD.

Bruner, J. (1996). Bir Öğretim Kuramına Doğru. (Fatma Varış ve Tanju Gürkan, Çev.). Ankara: Ankara Üniversitesi Basımevi.

Bybee, R. W. (1998). Bridging science and technology. The Science Teacher. 65(6), 3842.

Casaj, F. (1999). Public understanding of science: Using technology to enhance school science in everyday life. International Journal of Science Education, 21(7), 765773.

Chi, M.T.H. (2005). Commonsense conceptions of emergent processes: Why some misconceptions are robust. The Journal of the Learning Sciences, 14(2), 161-199.

Cobern, W. W., Gibson, A. T. \& Underwood, S. A. (1995). Valuing scientific literacy. The Science Teacher. 62(9), 28-31.

Çalık, M. \& Ayas, A. (2005). A comparison of level of understanding of eighth-grade students and science student teachers related to selected chemistry concepts, Journal of Research in Science Teaching, 42(6), 638-667. 
Çepni, S. (2010). Araştırma ve Proje Çalışmalarına Giriş (5. Baskı). Trabzon: Üçyol Kültür Merkezi.

Çepni, S., Bayraktar, Ş., Yeşilyurt, M. \& Coştu, B. (2001). Illköğretim 7. sınıf öğrencilerince hal değişimi kavramının anlaşılma seviyelerinin tespiti. Yeni Bin Yılın Başında Türkiye'de Fen Bilimleri Eğitimi Sempozyumu Bildiriler Kitabı (s.120-126). İstanbul.

Demir, M. K. (2005). İlköğretim fen bilgisi öğretmen adaylarının fen bilgisi alanına karşı tutumlarındaki değişimin tespiti (Yayınlanmamış yüksek lisans tezi), Yüzüncü Y11 Üniversitesi, Van.

Douvdevany, O., Dreyfus, A. \& Jungwirth, E. (1997). Diagnostic instruments for determining junior high-school science teachers' understanding of functional relationships within the "living cell". International Journal of Science Education, 19(5), 593-606.

Fortus, D., Krajcik, J., Charles, D., Marx, R. W. \& Mamlok-Naaman, R. (2005). Design-7. based science and real-world problem-solving. International Journal of Science Education, 27(7), 855-879.

Göçmençelebi, Ş.İ. \& Özkan, M. (2009). İlköğretim 6. sınıf öğrencilerinin fen bilgisi biyoloji konularını günlük yaşam ilişkilendirme düzeylerinin başarıya etkisi. Kastamonu Eğitim Dergisi, 17(2), 525-530.

Güngör, B. \& Özgür, S. (2009). İlköğretim 5. sınıf öğrencilerinin sindirim sistemi konusundaki didaktik kökenli kavram yanılgılarının nedenleri. Necatibey Eğitim Fakültesi Dergisi, 3(2), 149-177.

Güneş, B. (2010). Fizikteki Kavram Yanılgıları (Kişisel web sayfası). 11 Mayıs 2010.

Halim, L. \& Meerah, S.M. (2002). Science trainee teachers' pedagogical content knowledge and its infuence on physics teaching. Research in Science \& Technological Education, 20(2), 215-226.

Hamman, M. \& Prenzel, M. (2008). Ergebnisse des internationalen PISA naturwissenschaftstests 2006. Der Mathematische und Naturwissenschaftliche Unterricht, 61(2), 67-74.

Harlen, W. (2002). Links to everyday life: The roots of scientific literacy. Primary Science Review, 71, 8-10.

Kalaycı, Ş. (2008). SPSS Uygulamalı Çok Değikenli İstatistik Teknikleri (3.Bask1). Ankara: Asil Yayın Dağıtım.

Kavak, N., Yüksel, T. \& Demirelli, H. (2006). Fen-teknoloji okuryazarlığ1 ve informal fen eğitimi: Gazetelerin potansiyel rolü. Gazi Eğitim Fakültesi Dergisi, 3(26), 1728.

Kıyıcı-Balkan F. (2008). Fen bilgisi öğretmen adaylarının günlük yaşamları ile bilimsel bilgileri ilişkilendirebilme düzeyleri ve bunu etkileyen faktörlerin belirlenmesi (Yayımlanmamış doktora tezi), Gazi Üniversitesi, Ankara. 
Liu, X. (2009). Beyond science literacy: Science and the public. International Journal of Environmental \& Science Education, 4(3), 301-311.

Milli Eğitim Bakanlığı (2013). İlköğretim Fen Bilimleri Programı (3-8). Ankara: Talim Terbiye Kurulu.

McCann, W. R. (2001). Science education and everyday action (Unpublished doctoral dissertation), Ohio State University, USA.

McDermott, L.C. (2003). Improving student learning in sciences. Physical Science News, 4(2), 6-10.

OECD (2003). The PISA 2003 assessment framework - mathematics, reading, science and problem solving knowledge and skills. Paris:OECD Publishing.

Özden, Y. (2003). Öğrenme ve Öğretme (5. Bask1). Ankara: Pegem A Yayıncılık.

Özmen, H. (2003). Kimya öğretmen adaylarinin asit ve baz kavramlariyla ilgili bilgilerini günlük olaylarla ilişkilendirebilme düzeyleri. Kastamonu Eğitim Dergisi, 11(2), 317-324.

Senemoğlu, N. (2009). Gelişim, öğrenme ve öğretim: Kuramdan uygulamaya. Ankara: Pegem A Yayıncilık.

Smith, M. U. \& Siegel, H. (2004). Knowing, believing, and understanding: What goals for science education?. Science \& Education, 13, 553-582.

Wagner, W. (2007). Vernacular science knowledge: its role in everyday life communication. Public Understanding of Science, 16, 7-22.

Yaman, M. (2009). Solunum ve enerji konusunda öğrencilerin ilgisini çeken bağlam ve yöntemler. Hacettepe Üniversitesi Eğitim Fakültesi Dergisi. 37, 215-228. 


\section{Ekler}

\section{Ek-1. Fen Okuryazarlık Testi (FOYT)}

1. Kaynama nedir? Örnek vererek açıklayınız.

2. Donma nedir? Örnek vererek açıklayınız.

3. Erime nedir? Örnek vererek açıklayınız.

4. Boşaltım nedir? İnsanın boşaltım sistemini oluşturan yapıları yazınız.

5. Sindirim nedir? Sindirim organlarını yazınız.

6. Genleşme nedir? Katı, sıvı ve gazlarda genleşme için birer örnek veriniz.

7. Isı ve sıcaklık kavramlarını tanımlayarak aralarındaki farklılıkları yazınız.

\section{Ek-2. GYIT'e Yönelik Örnek Soru}

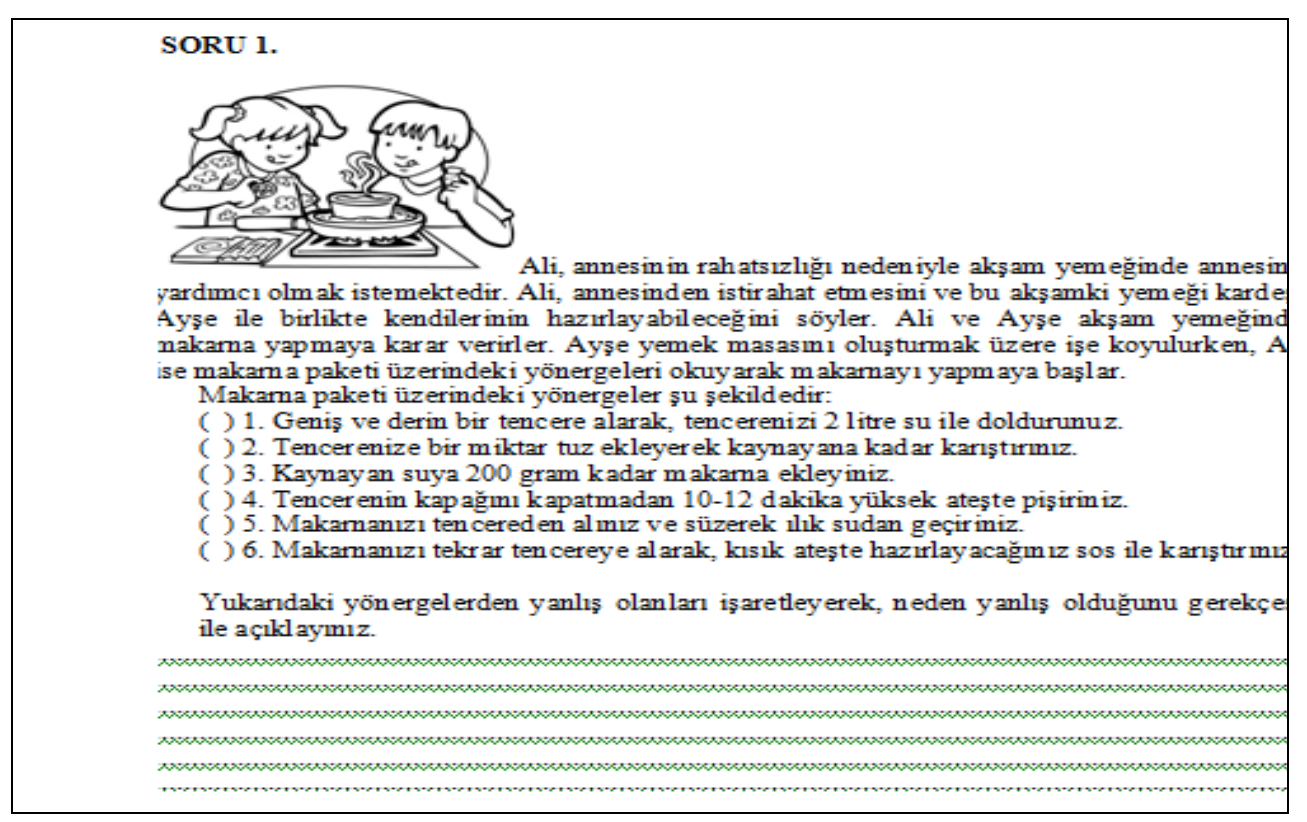

